\title{
UMA NOVA PERSPECTIVA NA TRADUÇÃO DE VARIEDADES LINGUÍSTICAS NO BRASIL: UM ESTUDO PRELIMINAR
}

\author{
A NEW PERSPECTIVE ON THE TRANSLATION OF LINGUISTIC VARIETIES IN \\ BRAZIL: A PRELIMINARY STUDY
}

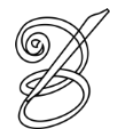 \\ Cassiano Teixeira de Freitas Fagundes ${ }^{1}$ \\ Mestrando em Estudos da Tradução \\ PGET - UFSC \\ cassimf@gmail.com
}

Resumo: No Brasil, representações de variedades linguísticas em textos literários estrangeiros tendem a ser traduzidas através de estratégias normalizadoras. Consequentemente, a função da variedade no texto de partida é perdida. Contudo, há hoje traduções que consideram a representação de elementos orais distintos da norma culta dos textos-fonte nos textos de chegada. Uma exceção à tendência é Ratos e Homens (2005), tradução de Ana Ban para Of Mice And Men (1937), de John Steinbeck. Examinaremos tal texto de chegada para identificarmos estratégias, descritas por Rosa (2012), que poderiam ser adotadas em um trabalho futuro: a tradução de um trecho de Bound For Glory (1943) de Woody Guthrie, que caracterize as variedades linguísticas deste texto de acordo com seu papel em seu contexto de origem. O livro não tem traduções publicadas para o Português até o presente momento. Baseamos nossa abordagem na noção descrita por Pascale Casanova (2002), de tradução como mediadora de intercâmbios culturais entre espaços literários dominantes e dominados. Nestes últimos, a autora observou a introdução da oralidade em suas literaturas como uma estratégia de aquisição de recursos literários.

Palavras-Chave: Tradução Literária; Variedades Linguísticas; Oralidade; Woody Guthrie; John Steinbeck.

Abstract: In Brazil, representations of linguistic varieties of literary source texts tend to be dealt with normalizing translation strategies. Consequently, the function of the variety according to its role in the source text is lost. However, there are translations today that consider the representation of oral language divergent from the standard language of the source texts in the target texts. One exception to the usual strategy is Ratos e Homens (2005), a Brazilian Portuguese translation by Ana Ban of Of Mice And Men (1937), by John Steinbeck. We focused on it to identify procedures and strategies, as described by Rosa (2012) that could be adopted in a translation to be carried out of an excerpt of Bound For Glory (1943) by Woody Guthrie, which would characterize its linguistic varieties according to their role in their context of origin. This book does not have any published translations into Portuguese up to the present moment. We based our approach on the notion described by Pascale Casanova (2002) of translation as a mediator of asymmetrical relations of cultural exchanges between dominant and dominated literary spaces. In the latter, the author noted the introduction oforality in their literatures as a strategy of acquisition ofliterary resources.

Key words: Literary Translation; Linguistic Varieties; Oral Language; Woody Guthrie; John Steinbeck.

FAGUNDES. Uma nova perspectiva na tradução de variedades linguísticas no Brasil: um estudo preliminar Belas Infiéis, v. 4, n. 1, p. 21-38, 2015. 


\title{
1. Introdução
}

tradução de variedades linguísticas ${ }^{2}$ na literatura segue sendo um tema espinhoso no
Brasil. Em O Clube do Livro e a Tradução (2002) MILTON já mostrara que não se
espera do tradutor que as traduza, e apontou algumas razões mercadológicas e ideológicas para isso. Ao se deparar com variedades no texto-fonte em língua estrangeira, o tradutor, na maioria das vezes regulado pela editora contratante, usaria estratégias normalizadoras para substituir o discurso estrangeiro com menos prestígio por um com mais prestígio na cultura de chegada. Contudo, doze anos depois da publicação do livro, há exemplos, no polissistema brasileiro de literatura traduzida, de traduções que consideram a representação de elementos orais dos textos-fonte, através de estratégias como a utilização do português brasileiro distinto da norma culta. HANES (2013, p. 193), que analisou uma pequena amostra de estudos de caso sobre a tradução de variedades linguísticas e dialetais da literatura estrangeira no Brasil, concluiu que:

\begin{abstract}
As recentes traduções e retraduções de obras literárias que utilizam o português divergente da norma culta, como no caso do discurso de Huckleberry Finn, poderiam apontar para uma futura mudança de paradigma, mas tal especulação não pode ser corroborada pela pequena amostra examinada neste estudo. Ainda assim, essa possibilidade sem dúvida se confirmará ou será refutada pelas pesquisas futuras sobre o tema.
\end{abstract}

Apesar da escassez de estudos mais gerais sobre o tema que atestem essa mudança de paradigma, pode-se especular que há uma tendência crescente em se considerar a variedade linguística dos textos-fonte com algum cunho político-social no texto de chegada. Segundo Hanes, seria o caso das traduções e retraduções mais recentes de A Cor Púrpura, Laranja Mecânica, As Aventuras de Huckleberry Finn, Pigmalião e Ratos e Homens. A "função social do discurso em cada uma dessas obras não parece ser negada, pois é parte intrínseca de cada história” (Ibidem, p. 191).

Exemplo de texto-fonte com forte conteúdo político-social, Of Mice And Men (1937), de John Steinbeck, faz um recorte do contexto sociocultural da Califórnia durante a Grande Depressão. As representações usadas por Steinbeck de variedades linguísticas divergentes da língua inglesa normativa cumprem, acima de tudo, a função de assinalar os contrastes e conflitos entre trabalhadores e seus patrões, membros da elite, nas fazendas do estado norte-americano.

FAGUNDES. Uma nova perspectiva na tradução de variedades linguísticas no Brasil: um estudo preliminar Belas Infiéis, v. 4, n. 1, p. 21-38, 2015. 
Em um estudo de caso abrangente, Of Mice And Men, de John Steinbeck: a Oralidade na Literatura Como Problema de Tradução, FARIA (2009) enfocou três traduções publicadas no Brasil do livro, em uma análise descritiva e comparativa de três traduções do mesmo, publicadas no Brasil em diferentes épocas. A primeira é de Érico Veríssimo (Porto Alegre: Editora do Globo, 1940); a segunda é de Myriam Campello (São Paulo: Círculo do Livro, 1991); e a terceira é de Ana Ban (Porto Alegre: L\&PM, 2005).

Sem atribuir juízo de valor a elas, ressaltou o papel de cada uma dessas reescrituras em relação ao tempo, espaço geográfico, à individualidade de cada autor e às relações com agentes como editoras, entre outros fatores. Faria mostra como Ana Ban tentou representar a linguagem estigmatizada usada pelas personagens de Of Mice And Men, o que também foi feito por Myriam Campello, mas de forma mais limitada. Já a tradução de Veríssimo praticamente apagou os registros dialetais do texto-fonte. $\mathrm{O}$ pesquisador concluiu que o uso de uma linguagem na tradução que se limite a representar os marcadores essenciais da língua traduzida poderia caracteriza-la segundo o seu papel desempenhado em seu contexto de origem.

A tradução de Ana Ban é a mais recente das três, e parece apontar para essa possível quebra de paradigma que estaria em curso no polissistema brasileiro de tradução literária. Em entrevista à Faria, a própria tradutora revelou ter optado por um "dialeto brasileiro do interior de São Paulo e Minas Gerais” (Ibidem, p. 118). Contudo, veremos adiante que muitos elementos usados por Ban para recriar as variedades de Of Mice And Men já têm o uso disseminado em todo o território brasileiro. Essa representação de uma oralidade estigmatizada, desviante da norma padrão, parece ser uma estratégia que diverge da simples substituição da variedade estigmatizada do texto-fonte por uma com mais prestígio na cultura de chegada. O procedimento de se usar marcadores dialetais não específicos a uma dada variedade diatópica em uma tradução de variedades linguísticas estigmatizadas nos parece uma estratégia válida e coerente.

Os estudos dialetológicos feitos no Brasil nos mostram que determinadas características da fala não-padrão estão espalhadas pelo território com uma regularidade que permite ao tradutor usá-las em seu trabalho sem incorrer no risco de apresentar ao leitor uma visão estereotipada ou caricata do outro. (CARVALHO, 2006. P. 1860)

FAGUNDES. Uma nova perspectiva na tradução de variedades linguísticas no Brasil: um estudo preliminar Belas Infiéis, v. 4, n. 1, p. 21-38, 2015. 
O objetivo de nossa pesquisa é testar essa estratégia, que é a tradução de representações de variedades linguísticas estrangeiras estigmatizadas na literatura através de uma recriação baseada em características da fala não-padrão encontradas no território brasileiro. Para atingir tal objetivo, traduziremos em um segundo momento de nossa pesquisa um trecho contendo variedades linguísticas de Bound For Glory, do músico e escritor norte-americano Woody Guthrie $^{3}$. O fato de o livro ter conteúdo de cunho sociocultural e político por si só justificaria a consideração de suas variedades linguísticas no texto de chegada. Como a obra de Guthrie não tem traduções publicadas para o português, recorremos à obra traduzida de John Steinbeck. O autor estadunidense não apenas retratou grupos socioculturais similares aos de Bound For Glory, como também representou suas variedades linguísticas, muito parecidas às contidas no texto de Guthrie.

O caminho mais lógico teria sido enfocarmos traduções de The Grapes of Wrath ${ }^{4}$ (1939), de Steinbeck, que retrata experiências e grupos mais próximos - sobretudo os okies ${ }^{5}$ - aos de Bound For Glory. No entanto, as traduções mais recentes do livro, de Herbert Caro e Ernesto Vinhaes, publicadas sob o título As Vinhas da Ira (2004), foram descartadas por terem um uso comedido de reduções, coloquialismos e outros elementos que constituem variedades linguísticas, além de uma falta de consistência em seu uso, e oscilação entre marcadores do dialeto nordestino e caipira, além do dialeto padrão (PEREZ, 1993). Muitos marcadores dialetais também não teriam sido considerados, o que homogeneizou alguns trechos marcados pela contraposição entre a variedade padrão e o dialeto estigmatizado, havendo então o comprometimento do estilo da obra, e a caracterização das personagens.

\section{As variedades linguísticas em Of Mice And Men e Bound For Glory}

John Steinbeck e Woody Guthrie usaram representações similares de variedades linguísticas das personagens, também próximas historicamente e em sua origem sociocultural. A exemplo, Steinbeck utilizou muitos coloquialismos, como “oughta” (ought to), outta (out of) e "awready" (already); O desaparecimento do "g” do final de algumas das palavras, como em “tellin”” (telling), “hidin”” (hiding) e “nothin”” (nothing), também é comum. 
Vejamos outros marcadores linguísticos usados na fala das personagens na seguinte cena, da página 7. George e Lennie estão à beira do rio Salinas. Lennie tenta esconder um rato de George:

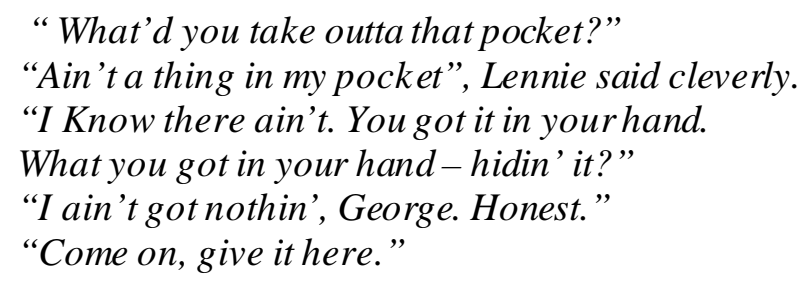

Vemos neste diálogo: 1 - a contração do verbo auxiliar do em What'd. 2 - o coloquialismo outta, referente a out of. 3 - $\mathrm{O}$ uso da contração Ain't, relativa à There is not. Interessante notar que essa contração é tradicionalmente associada ao discurso de "pessoas comuns" ou de "classe baixa”, e seu uso é frequentemente desencorajado por professores e pais (GILMAN, 1989. p. 33). 4 - Eliminação de “g” do final das palavras, como em hidin’ e nothin’.

Em outro capítulo, Lennie conta para o negro Crooks o sonho que ele e George alimentam de terem sua própria propriedade, onde cultivariam a terra e teriam uma criação de coelhos. Crooks levanta a possibilidade de George, que foi beber na cidade com alguns de seus companheiros, não voltar mais. Na página 70, Crooks diz:

“Well, s’pose, jus's'pose he don't come back. What'll you do then?”

Um pouco mais adiante, Candy se junta a eles e expressa sua esperança de concretizar o plano ao lado de George e Lennie. Crooks, desdenhando a ideia, diz, na página 74:

\section{“You guys is just kiddin’ yourself. (...)”.}

Nos dois extratos, vemos os seguintes elementos: 1 - a redução jus’ para just. 2 - o coloquialismo formado pela contração de suppose, em s’pose. 3 - conjugação agramatical da forma negativa do verbo auxiliar do em don't, ao invés de he doesn 't. 4 - conjugação divergente do verbo to be em "You guys is”, que está no singular (is) e não concorda com o sujeito guys (are). 5 - uso da redução kiddin’ para kidding. 
No mesmo capítulo, a esposa de Curley se aproxima dos três, que conversam no quarto de Crooks. Candy diz a ela, na página 76:

'You gotta husban'. You got no call foolin' aroun' with other guys, causin' trouble."

Mais adiante, a garota diz:

“Sati'day night. Ever'body out doin' som'pin. Ever'body! An' what am I doin'? Standin' here talkin' to a bunch of bindle stiffs - a nigger an' a dum-dum and a lousy ol'sheep - an' likin' it because they ain't nobody else.".

Novamente, vemos coloquialismos como gotta para got a, Sati'day para Saturday, Ever'body para Everybody. Também vemos reduções do "g" do final das palavras como em doin' para doing, foolin' para fooling, talkin' para talking e likin' para liking, entre outras. Além disso, há reduções da letra "d” do final das palavras como em husban' para husband e aroun' para around e An' para And e a contração ol'sheep para old sheep. Notemos, no entanto, que as reduções das letras "g”, "d" e "t" dos finais de palavras nem sempre acontecem, e não seguem um sistema. No mesmo diálogo entre Lennie e Crooks citado acima, Crooks diz, na página 69:

"This is just a nigger talkin', an' a busted-back nigger. So it don't mean nothing."

Como vimos antes, a mesma personagem reduz a letra “t” de just em jus', o que aqui não acontece. Podemos argumentar que Steinbeck queria, acima de qualquer coisa, caracterizar a fala desviante da norma padrão, e não retratar com exatidão tal fala, como em um tratado de linguística.

Vejamos agora as variedades linguísticas de Bound For Glory. Na página 31, encontramos Guthrie na parte superior de um vagão de trem com um viajante negro que acaba de conhecer. Os dois travam o seguinte diálogo:

"Smell dat cool aih?"

"Smells clean. Don't it? Healthy!"

"Me ' $n$ ' you's sho' in fo' a soakin', ourselves!”

"Makesya think?"

"I knows. Boy, up heah in dis lake country, it c'n cloud up an' rain in two secondsflush!”

FAGUNDES. Uma nova perspectiva na tradução de variedades linguísticas no Brasil: um estudo preliminar Belas Infiéis, v. 4, n. 1, p. 21-38, 2015. 
"Ain't no rain cloud I can see!"

"Funny thing 'bout dese Minnesoty rain clouds. Evah cloud's a rain cloud!”

"Gonna go hard on my guitar."

Vemos aqui alguns elementos que ajudam a representar variedades estigmatizadas, como: 1 - Substituição de th por d em dat, dis, dese;

2 - Redução do "r" no final das palavras, como em aih e fo";

3 - Redução do “g” como em soakin’ e do “d” como em an’;

4 - Coloquialismos formados por contrações, substituições e outros, como c’n, Gonna, Ain’t, ya, etc.

Na página seguinte, dois garotos se juntam a eles. O viajante negro lhes faz um comentário:

\footnotetext{
"You gents is a little shade yo'ng t' be out siftin' th' cinders, ain't you?"

"C'n we help how old we are?" The biggest kid spit away into the wind without even looking where it would land.

"Me ole man's fault. Oughtta been bornt sooner.", the little runt piped up.
}

Aqui encontramos os mesmos elementos, mais coloquialismos como yo’ng, ole, Oughtta e bornt, além de conjugações verbais agramaticais como gents is.

De modo geral, representações de variedades linguísticas são encontradas em todo o livro com certa regularidade.

Alguns marcadores linguísticos evidenciam a similaridade de uso entre os dois autores: 1 - Apócopes: o desaparecimento do “g” do final de palavras, como em hidin', kiddin', siftin' e outros. O desaparecimento de “d” do final de palavras, como em aroun' e an'; 2 - Coloquialismos formados por contrações como oughta/oughtta, ain't, C’n;

3 - Conjugações verbais agramaticais em que há divergência de pessoa ou número entre determinante e verbo, como em I knows e You guys is.

Esta análise preliminar nos mostrou um fato: muitos dos elementos utilizados pelos autores estadunidenses, como oughta e outta, são marcadores linguísticos do vernáculo do inglês norte-americano, e não têm seu uso restrito a variedades estigmatizadas. Isso é evidência de que a representação de variedades linguísticas pode em grande parte depender de marcadores 
linguísticos utilizados na oralidade, disseminados além de limites diatópicos e diastráticos e não restritos a grupos falantes de variedades estigmatizadas. Examinaremos essa ideia mais adiante.

\section{Estratégias para a tradução de variedades linguísticas}

As variedades linguísticas são por si só traduções de uma dimensão extralinguística. Chamadas alternativamente por Lane-Mercier de socioletos literários, são, acima de tudo, representações textuais, e não discurso autêntico. ROSA (2012) explica que a diferença entre as variedades linguísticas autênticas e suas representações se deve à aplicação de filtros e restrições em sua configuração ficcional e literária. Dentre eles, “[...] estereótipos sociolinguísticos (que) organizam os dados brutos da variação linguística autêntica em categorias prontas e aplicáveis, correlacionando formas, sentido comunicativo e valor sócio-semiótico”6 (Ibidem, p. 82). O valor extralinguístico evoca uma hierarquia de prestígio, orientada pelo discurso dominante, que motiva tais categorias.

Outro filtro seria um "repertório de marcadores seletivos” conhecidos e previamente usados. O terceiro diz respeito à função da variedade linguística na narrativa do texto de partida. Rosa também salienta que:

[...] tal recriação seletiva e filtrada nunca é livre de restrições, como a necessidade de legibilidade, o grau de consciência da variação em uma determinada comunidade linguística, o meio, a complexidade do enredo, entre outros. Tais filtros e a sua validade são, como tal, contextualmente motivados e, como consequência, intrinsecamente associados a um dado espaço e tempo (Ibidem, p. 82) ${ }^{7}$.

Rosa desenvolveu uma classificação de procedimentos de tradução de variedades literárias, baseada no uso de "marcadores linguísticos formais assinalando sentido contextual associado a discurso com menos prestígio"8 (Ibidem, p. 85). Ela foi concebida para ser aplicável a traduções para o português europeu, mas acreditamos que ela também possa ser usada para o português brasileiro. Ela dividiu os tipos de traduções em quatro categorias: (1) Omissão; (2) Adição; (3) Manutenção; e (4) Mudança - quando, por exemplo, a variedade do texto-fonte é social e no texto de chegada se torna regional. Ou ainda, quando há uma mudança de uma variedade não-padrão mais periférica para uma menos periférica, ou vice-versa.

FAGUNDES. Uma nova perspectiva na tradução de variedades linguísticas no Brasil: um estudo preliminar Belas Infiéis, v. 4, n. 1, p. 21-38, 2015. 
Notemos que, segundo a classificação, na grande maioria dos casos, há alterações e substituições de marcadores linguísticos que caracterizam variedades linguísticas, que "não são determinadas por diferenças sistêmicas e formais. A maioria das alterações não são obrigatórias, e governadas por normas, contextualmente motivadas por razões culturais, ideológicas e políticas” ${ }^{9}$ (p. 86). As alterações, microestruturais, são fatos da cultura de chegada, que, agrupadas de forma consistente, constituem estratégias de tradução, em um nível macroestrutural.

Rosa também descreve as principais estratégias na tradução de variedades linguísticas: (1) Normalizadora, que tende a substituir as variedades literárias de menos prestígio do texto fonte pela variedade com mais prestígio na cultura de chegada: a normativa; (2) Centralizadora, que substitui as variedades estigmatizadas do texto-fonte, por representações que aludam a variedades estigmatizadas mais próximas da língua normativa, ainda que sugiram algum desvio da norma. A autora também cita a pesquisa de DIMITROVA (1997), que identificou o uso de coloquialismos da língua normativa para se traduzir variedades estigmatizadas do texto-fonte; e (3) Descentralizadora, que consiste na substituição de uma representação de variedade linguística estigmatizada do texto-fonte por outra estigmatizada na cultura de chegada. Esta, que gostaríamos de enfocar, pode ser feita através de procedimentos de adição e mudança de "marcadores linguísticos assinalando sentido contextual associado a discurso com menos prestígio".

\section{A tradução de Ana Ban para as variedades de Of Mice And Men}

Lançada em 2005 pela L\&PM, a tradução de Ana Ban, intitulada Ratos e Homens, é uma publicação de bolso e faz parte da coleção L\&PM Pocket. A representação de variedades linguísticas do texto-fonte de John Steinbeck foi assinalada no texto de chegada de Ban por marcadores linguísticos seletivos, reconhecidos dentro do contexto linguístico nacional, e que sugerem a fala não padrão no português brasileiro. Isso parece gerar um contraste com o discurso indireto do narrador, este mais próximo da norma padrão. Respondendo a um questionário enviado pelo pesquisador Johnwill Costa Faria, a tradutora disse, sobre sua abordagem na tradução de Of Mice And Men:

FAGUNDES. Uma nova perspectiva na tradução de variedades linguísticas no Brasil: um estudo preliminar Belas Infiéis, v. 4, n. 1, p. 21-38, 2015. 
Em um primeiro momento, eu resolvi que iria seguir a norma culta em todo o livro, mas depois achei que assim a ideia do autor não seria transmitida de maneira adequada (isso tudo foi discutido com a editora). Então eu peguei um "sotaque caipira" que eu conheço, mais ou menos do interior de SP/MG (apesar de a L\&PM ser em Porto Alegre e eu atualmente morar aqui, sou de São Paulo e passei a maior parte da minha vida lá) e seguiesta linha. (BAN, 2008, apud COSTA FARIA, 2009, p. 118)

Evidenciamos aqui uma preocupação de Ban com a função da variedade linguística no texto-fonte de Steinbeck, e como o que chamou de "ideia do autor" não seria transmitida adequadamente se ela simplesmente usasse a norma culta na tradução. Ela revelou que não possui nenhuma formação teórica, embora tenha algum conhecimento teórico. Disse ter feito um curso de tradução "prático e direto, [que] não aborda teorias". (Ibidem, p. 118). Costa Faria sugere que a utilização de marcadores linguísticos que remetam a um falar do interior de São Paulo e Minas Gerais seria uma domesticação, de acordo com a teoria de VENUTI (1997). Contudo, a própria tradutora afirma não "aplicar" as teorias da qual tinha conhecimento conscientemente durante o processo de tradução. Pode-se então pensar que Ban não tinha uma estratégia clara para traduzir Of Mice And Men, fora a decisão de considerar a maneira de suas personagens falarem. Há uma evidência de que ela se concentrou nos marcadores linguísticos do texto-fonte e em sua tradução:

[...] a maior dificuldade foi mes mo a transposição da maneira como os personagens falavam - eu não sei se chega a ser um dialeto, porque na verdade eram mais erros gramaticais e pronúncia errada, não havia tantas palavras específicas que fossem desconhecidas ou usadas com sentido fora do mais comum. (BAN, 2008, apud COSTA FARIA, 2009, p. 118)

Para ilustrar como Ban lidou com essa dificuldade, vejamos sua tradução, comparada à de Myriam Campello, em um dos trechos de Of Mice And Men:

FAGUNDES. Uma nova perspectiva na tradução de variedades linguísticas no Brasil: um estudo preliminar Belas Infiéis, v. 4, n. 1, p. 21-38, 2015. 


\begin{tabular}{|c|c|c|}
\hline $\begin{array}{l}\text { Ratos e Homens - Tradução } \\
\text { de Myriam Campello }\end{array}$ & $\begin{array}{l}\text { ttos e Homens - Tradução } \\
\text { Ana Ban }\end{array}$ & $\begin{array}{l}\text { f Mice And Men - Texto de } \\
\text { artida }\end{array}$ \\
\hline $\begin{array}{l}\text { - Esses rapazes acabaram de chegar - } \\
\text { disse Slim, à guisa de apresentação. } \\
\text { - Muito prazer - disse o homem. - } \\
\text { Meu nome é Carlson. } \\
\text { - Eu me chamo George Milton e este } \\
\text { aqui é Lennie Small. } \\
\text { - Muito prazer - repetiu o homem. - ele } \\
\text { não é muito pequeno. (trocadilho com } \\
\text { o nome do personagem: "small” } \\
\text { significa "pequeno". Nota do Editor). } \\
\text { Riu suavemente da brincadeira. - Não } \\
\text { é pequeno de jeito nenhum. Queria te } \\
\text { perguntar, Slim, como vai sua cadela? } \\
\text { Notei que ela não foi com o carro essa } \\
\text { manhã. } \\
\text { - Deu cria ontem à noite - disse Slim. - } \\
\text { Nove filhotes. Afoguei logo quatro } \\
\text { deles. Ela não ia poder alimentar } \\
\text { tantos. } \\
\text { - Ficaram cinco, hem? } \\
\text { - É, cinco. Fiquei com os maiores. } \\
\text { - Que tipo de cachorro acha que vão } \\
\text { ser? }\end{array}$ & 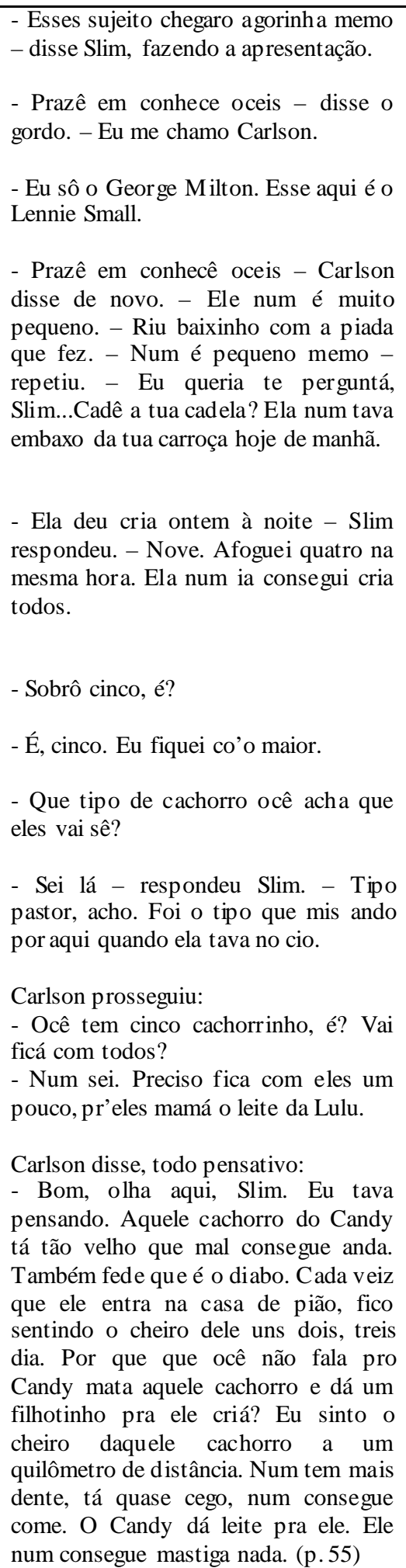 & $\begin{array}{l}\text { "This guys jus' come," Said Slim by } \\
\text { way of introduction." } \\
\text { "Glad ta meet ya," the big man said. } \\
\text { "My name's Carlson." } \\
\text { "I'm George Milton. This here's } \\
\text { Lennie Small." } \\
\text { "Glad ta meet ya," Carlson said } \\
\text { again. "He ain't very small at all." He } \\
\text { chuckled softly at his joke. "Ain't small } \\
\text { at all," he repeated. "Meant to ask } \\
\text { you, Slim - how's your bitch? I seen } \\
\text { she wasn't under your wagon this } \\
\text { morning." } \\
\text { "She slang her pups last night," said } \\
\text { Slim. "Nine of 'em. I drowned four of } \\
\text { 'em right off. She couldn't feed that } \\
\text { many." } \\
\text { "Got five left, huh?" } \\
\text { "Yeah, five. I kept the biggest." } \\
\text { "What kinda dogs you think they're } \\
\text { gonna be?” } \\
\text { "I dunno", said Slim. "Some kinda } \\
\text { sheperds, I guess. That's the most kind } \\
\text { I seen around here when she was in } \\
\text { heat." } \\
\text { Carlson went on, "Got five pups, huh. } \\
\text { Gonna keep all of 'em??" } \\
\text { "I dunno. Have to keep 'em a while so } \\
\text { they can drink Lulu's milk. } \\
\text { Carlson said, thoughtfully, "Well, } \\
\text { looka here, Slim. I been thinkin'. That } \\
\text { dog of Candy's is so God damn old he } \\
\text { can't hardly walk. Stinks like hell, too. } \\
\text { Ever' time he comes into the bunk } \\
\text { house I can smell him for two, three } \\
\text { days. Why'n't you get Candy to shoot } \\
\text { his old dog and give him one of the } \\
\text { pups to raise up? I can smell that dog } \\
\text { a mile away. Got no teeth, damn near } \\
\text { blind, can't eat. Candy feeds him milk. } \\
\text { He can't chew nothing else." }\end{array}$ \\
\hline
\end{tabular}

FAGUNDES. Uma nova perspectiva na tradução de variedades linguísticas no Brasil: um estudo preliminar Belas Infiéis, v. 4, n. 1, p. 21-38, 2015. 
Nos textos de chegada, nota-se um bom número de coloquialismos e usos encontrados no vernáculo geral brasileiro (BAGNO, 2011) e suas variedades. Alguns exemplos:

- Eliminação de "s" em final de palavra, por força de economia linguística: morfologia de plural preservada no determinante (Ibidem, p. 336), como em Esses sujeito. Essa solução para This guys no texto-fonte é muito interessante, porque preserva a tensão entre o determinante This (singular) e guys (plural). Esse tipo de marcador é muito usado em Of Mice And Men. Exemplo: You guys is (p. 74). A eliminação de "s" em final de palavra é percebida no Brasil como marca de variedade linguística estigmatizada, comumente usada no interior do país, embora também tenha uso comum em variedades urbanas.

- Metaplasmos brasileiros, como a desnalização em relação à vogal nasal postônica, de uso frequente no Brasil, até mesmo em variedades urbanas de prestígio (, 2011, p. 329), como em chegaro para chegaram. No trecho acima, Ban estabeleceu uma correspondência numérica de marcador linguístico, que na sentença do texto-fonte

- Apócopes, com ocorrências no Brasil não apenas em variedades linguísticas estigmatizadas, mas também em variedades urbanas de prestígio em contextos de interação menos monitorada (Ibidem, p. 335), como a redução do "r” no final das palavras em criá para criar, ficá para ficar e mamá para mamar.

Valendo-se apenas dos exemplos acima, pode-se supor que, ao contrário do que afirmou Ban, nem todos os elementos utilizados para caracterizar as variedades do texto-fonte têm uso restrito ao português interiorano de Minas Gerais e São Paulo, e são característicos do vernáculo geral brasileiro.

Recorrendo à classificação de Rosa, em relação aos marcadores linguísticos que denotem discurso com menos prestígio, a estratégia de Ban para a tradução das variedades linguísticas de Of Mice And Men foi a de manutenção, embora as ocorrências no texto-fonte e no texto de chegada não tenham números idênticos. Também podemos inferir que é uma estratégia que tende à centralização: a representação de discurso estigmatizado e desviante da norma culta do textofonte foi feita no texto de chegada em grande parte através de elementos que remetem a um discurso desviante da norma padrão na cultura de chegada, mas com uso mais disseminado e 
comum na cultura de chegada. Para averiguarmos isso, seria interessante listar quais marcadores do texto de partida têm uso mais disseminado e menos restrito de maneira diatópica e diastrática, e quais são próprios de localidades e grupos socioculturais específicos. O mesmo deveria ser feito em relação aos marcadores usados da língua de chegada.

Em muitos casos, o vernáculo geral brasileiro foi usado para representar a oralidade das personagens do texto-fonte. Na tradução, esse discurso direto contrasta com o discurso indireto, mais próximo da norma culta. Podemos inferir então que, dentre as estratégias de tradução de representações de variedades linguísticas estrangeiras na literatura, uma delas é o uso vernacular e coloquial do português brasileiro.

Ana Ban optou por traduzir as variantes dialetais de Of Mice And Men através de uma distinção diastrática, que remete ao falar do homem simples do interior, que também é diatópica, ainda que não específica a uma região/estado/localidade do espaço brasileiro. Também se poderia afirmar que tem ao mesmo tempo uma função social e didática no polissistema de chegada, o brasileiro, ao apresentar variedades além da norma padrão que também são passíveis de serem literárias. CARVALHO (2006, p. 1860) diz, a favor da tradução de variantes dialetais:

[...] As variantes dialetais podem e devem ser traduzidas; qualquer proposta de tradução terá suas perdas e ganhos, mas um tradutor não pode alegar uma pretensa neutralidade ou a impossibilidade de tradução com o intuito de evitar fazer um trabalho que poderá engrandecer o texto traduzido.

\section{Conclusão}

Quando Ana Ban recorreu a o que achava ser a fala do habitante do interior dos estados de São Paulo e Minas Gerais para representar as variedades linguísticas estigmatizadas de Of Mice And Men, ela em grande parte utilizou marcadores linguísticos cujo uso não é restrito a estas áreas. São, sobretudo, elementos do vernáculo geral brasileiro, com uso feito não apenas por falantes de variedades linguísticas do interior do país e estigmatizadas, mas também em variedades urbanas com mais prestígio. Tal constatação ainda merece ser expandida em estudos futuros que a confirme ou a refute.

O fato é que, à semelhança da tradução de Ban, os textos-fonte de John Steinbeck e Woody Guthrie contêm muitos marcadores linguísticos que remetem ao vernáculo da língua em questão, 
e não são restritos a variedades linguísticas estigmatizadas e históricas. Assim como a tradutora não tinha a intenção de recriar minuciosamente as falas dos trabalhadores norte-americanos em português brasileiro, Steinbeck e Guthrie também não fizeram ou pretendiam fazer tratados linguísticos que documentassem com precisão variedades específicas. É bom lembrar que, quando falamos de variedades linguísticas na literatura, tratamos nada mais do que representações de variedades vernáculas reais, com funções específicas dentro do contexto da narrativa.

De modo geral, a tradução de Ban parece ter mantido o número de ocorrências de marcadores linguísticos remetendo a variedades estigmatizadas, usando para isso elementos que diferem da norma padrão do português e contribuem para a manutenção da heteroglossia do texto-fonte.

Contudo, só um exame mais extenso pode averiguar a hipótese de ser uma estratégia centralizadora, por traduzir o discurso divergente da norma culta do texto-fonte, na maioria das ocorrências, através de marcadores que remetam a variedades estigmatizadas mais próximas à norma culta na cultura de chegada - no caso, ocorrências mais disseminadas do vernáculo geral brasileiro, ou se ela primou em grande parte pela manutenção de marcadores assinalando sentido contextual associado a discurso com menos prestígio com distância correlata à entre a norma padrão e a variedade da cultura de partida. É possível que tal correlação seja de fato impossível de ser feita.

De qualquer forma, a estratégia descrita talvez possa ser uma manifestação precoce nesse possível novo paradigma em relação à tradução de variedades linguísticas no polissistema literário brasileiro. Tal estratégia minimizaria o risco de se tentar estabelecer correspondências irreais entre variedades linguísticas estrangeiras e variedades diatópicas/diastráticas brasileiras específicas.

Também é válido indagarmos se a representação da variedade linguística estrangeira através de elementos do vernáculo geral brasileiro e suas variedades pode ser entendida como capital linguístico para o polissistema literário brasileiro, e se essa estratégia ajudaria a diminuir o preconceito linguístico acerca das variedades do português brasileiro que divergem da norma culta, esta muitas vezes tão distante da língua que o brasileiro fala. A questão serve como um ideal em nossa pesquisa, e também merece uma investigação futura.

FAGUNDES. Uma nova perspectiva na tradução de variedades linguísticas no Brasil: um estudo preliminar Belas Infiéis, v. 4, n. 1, p. 21-38, 2015. 
Por fim, nosso próximo passo será traduzir um trecho de Bound For Glory usando uma estratégia semelhante à de Ana Ban, para testa-la e a contrapor a traduções do mesmo livro para outras línguas neolatinas. O objetivo é descobrir se tal expediente também é usado em outros polissistemas literários, e quais seriam os ganhos de sua adoção.

\section{REFERÊNCIAS BIBLIOGRÁFICAS}

AMARAL, Amadeu. O dialeto caipira. Anhembi, 1955. 186 p. Disponível em: $<$ http://www.dominiopublico.gov.br/download/texto/bi000004.pdf $>$. Acesso em: junho de 2014.

ANTONIO, Juliano Desiderato. (Org.). Estudos descritivos do português: história, uso e variação. São Paulo: Claraluz, 2008.

ARAUJO, Ruy Magalhães; MELO, Gladstone. Chaves; CUNHA, Celso.; AMARAL, Amadeu. História da Língua Portuguesa (Aspectos da Língua Portuguesa no Brasil). In: I Congresso Nacional de Linguística e Filologia, 1997, São Gonçalo, Rio de Janeiro, Livro de Resumos do I Congresso Nacional de Lingüística e Filologia, Rio de Janeiro: CiFeFiL/FFP, 1997. p. 65.

BAGNO, Marcos. Gramática pedagógica do português brasileiro. São Paulo: Parábola Editorial, 2011.

BEHIN, Bahran; SADEGHI, Bahra. A Linguistic Account of the Protagonist's Development in the Grapes of Wrath. The Journal of Applied Linguistics Vol. 3, Issue 1. Shahid Madani University Of Azarbaijan, 2010

CARVALHO, Solange Peixe Pinheiro. A tradução das variantes dialetais no Brasil: uma discussão das idéias de Gillian Lane-Mercier. Revista do GEL, Araraquara, 2006, p. 1859-60

CARVALHO, Solange Peixe Pinheiro. A tradução do socioleto literário: um estudo de Wuthering Heights. 2006, 218 f. Dissertação (Mestrado em Estudos Estilísticos e Literários em Inglês) - Faculdade de Filosofia, Letras e Ciências Humanas da Universidade de São Paulo.

CASANOVA, Pascale. A república mundial das letras. São Paulo: Estação Liberdade, 2002.

CATFORD, John Cunnison. Uma teoria linguística da tradução. Campinas: Ed. Cultrix, 1980.

DUBOIS, Jean, et al. Dicionário de Linguística. São Paulo: Cultrix, 2007.

ESTEVES, Lenita Maria. Rimoli. Algumas reflexões sobre a ética na tradução. Revista de Estudos Linguísticos XXXIV, p. 340-44, Campinas: UNICAMP 2005.

FAGUNDES. Uma nova perspectiva na tradução de variedades linguísticas no Brasil: um estudo preliminar Belas Infiéis, v. 4, n. 1, p. 21-38, 2015. 
EVEN-ZOHAR, Itamar. Polysistem Studies. Poetics Today. Inte rnational Journal for Theory and Analysis of Literature and Communication, Vol. 11, Number 1 Spring 1990.

FAGUNDES, Cassiano Teixeira de Freitas. A tradução literária no Brasil e os socioletos literários: uma nova proposta. 2006. 69 f. Monografia (Especialização em Inglês: Metodologia do Ensino e Tradução) - Pontifícia Universidade Católica do Paraná, 2006.

FARIA, Johnwill. Costa. Of mice and men, de John Steinbeck: a oralidade na literatura como problema de tradução. 2009, 219 f. Dissertação (Mestrado). Brasília: Universidade de Brasília, 2009.

GILMAN, E. Ward. Merriam Webster's Dictionary of English Usage. Merriam-Webster, 1989.

GUTHRIE, Woody. Bound for glory. New York: Penguin/Putnam, 1983.

HANES, Vanessa Lopes Lourenço. A tradução de variantes orais da língua inglesa no português do Brasil: uma aproximação inicial. Scientia Tradutionis, n.12, 2013, p. 178-196

HERMANS, Theo. Translation in Systems. Descriptive and System-oriented Approaches

Explained. Manchester, St. Jerome, 1999.

KLEIN, Joe. Woody Guthrie: A Life. New York : Ballantine Books. 1990.

LACERDA, Patrícia. F. A. Cunha. Tradução e sociolinguística variacionista: a língua pode traduzir a sociedade? Tradução e Comunicação - Revista Brasileira de Tradutores, n. 20, 2010, p. $127-42$

LAMBERT, José.; GORP, Hendrik. V. On describing Transaltions. In: HERMANS T. (Ed.). The Manipulation of Lite rature. Studies in Literary Translation. London \& Sidney, Croom Helm, 1985, p. 42-53.

LANE-MERCIER, Gillian. Translating the untranslatable: The Translator's Aesthetic, Ideological and Political Responsibility, Target 9:1, p. 43-68, 1997.

LEFEVERE, André. Translation, Rewriting and the Manipulation of Literary Fame. London/New York: Routledge, 1992.

MILTON, John. O clube do livro e a tradução. Bauru: EDUSC, 2002.

PEREZ, Selene Cuberos. The grapes of wrath: um exemplo de tradução de variantes linguísticas. 1993, 81 f. Dissertação (Mestrado em Semiótica e Linguística Geral). São Paulo: Universidade de São Paulo, 1993.

ROSA, Alexandra Assis. Translating place: linguistic variation in translation. Word and text - a journal of literary studies and linguistics. Bucareste. Vol. II, Issue 2, 2012, p. 75-97

FAGUNDES. Uma nova perspectiva na tradução de variedades linguísticas no Brasil: um estudo preliminar Belas Infiéis, v. 4, n. 1, p. 21-38, 2015. 
PYM, Anthony. "Translating linguistic variation: parody and the creation of authenticity". In: VEGA, Miguel A. e MARTÍN-GAITERO, Rafael (ed.). Traducción, metrópoli y diáspora. Madrid: Universidade Complutense de Madrid, 2000, pp. 69-75. Disponível em: $<$ http://goo.gl/kb0fZa> Acesso em: 04 de setembro de 2013.

STEINBECK, John, E. Ratos e Homens. Tradução de Érico Veríssimo. Porto Alegre, Editora Globo, 1940.

. The grapes of wrath. London: Penguin Books, 1963.

. Ratos e homens. Tradução de Myriam Campello. São Paulo, Círculo do Livro, 1991.

.; SHILLINGLAW, S. Of mice and men. London: Penguin Books, 1994.

As vinhas da ira. Tradução de Herbert Caro e Hernesto Vinhaes. Rio de Janeiro: Editora Record, 2004.

. Ratos e homens. Tradução de Ana Ban. Porto Alegre: L\&PM Editores, 2005.

TOURY, Gideon. "The Nature and Role of norms in translation”. Descriptive Translation Studies and Beyond, pp 53-69, Amsterdam/Philadelphia: John Benjamins, 1995.

VENUTI, Lawrence. The Translator's Invisibility: a history of translation. New York: Routledge, 1997.

${ }^{1}$ Currículo lattes Cassiano Teixeira de Freitas Fagundes. Disponível em: http://lattes.cnpq.br/4255286288720564

2 Variedades ou variantes linguísticas são formas de um determinado sistema linguístico, usadas por comunidades de falantes, e orientadas por eixos de diferenciação. Elas podem ser regionais (variantes diatópicas), socioculturais (variantes diastráticas), e contextuais (variantes diafásicas). (Dubois. et al, 2007).

${ }^{3}$ Woodrow Wilson Guthrie nasceu em 1912 em Okemah, Oklahoma (Estados Unidos). Aos dezenove anos, deixou sua terra natal e adotou o Texas como novo lar. Sobreviveu em parte como um músico, e pouco depois de se casar, começou sua viagem em direção à Califórnia, pegando carona, viajando clandestinamente em trens de carga e caminhando. Em Los Angeles, algumas de suas canções começaram a tocar no rádio e o levaram à fama. Em seguida, mudou-se para Nova Iorque, onde suas composições com forte apelo social foram adotadas por artistas e organizações de esquerda. Lá, gravou uma série de entrevistas e canções como folclorista Alan Lomax, em 1940. No final daquela década, fez parte do grupo de música folk de orientação esquerdista Almanac Singers. No estado do Oregon, participou de um documentário sobre a construção da represa Grand Coulee, compondo uma coleção de canções que viriam a se tornar muito populares, entre elas, This Land Is Your Land. Em 1943, publicou seu livro, Bound For Glory. Com a Segunda Grande Guerra, alistou-se na Marinha Mercante, e durante esse período, escreveu canções de cunho antifascista. Casou-se pela segunda vez em 1945 e se estabeleceu em Coney Island, subúrbio de Nova Iorque. Em 1954, internou-se num hospital no estado de Nova Jérsei, por conta de uma doença degenerativa, a Coréia de Huntington. Em 1967, depois de vários períodos em diferentes hospitais, Woody Guthrie faleceu, aos cinquenta e cinco anos de idade. (Klein, 1990).

FAGUNDES. Uma nova perspectiva na tradução de variedades linguísticas no Brasil: um estudo preliminar Belas Infiéis, v. 4, n. 1, p. 21-38, 2015. 
${ }^{4}$ The Grapes Of Wrath (1939), de John Steinbeck, enfoca uma família de meeiros do Oklahoma, os Joads, que é forçada a deixar a sua terra durante a grande depressão, despejada e castigada pela seca. O grupo se une a outros migrantes numa viagem até a Califórnia em busca de trabalho e de um futuro melhor. Os viajantes se congregam em acampamentos ao longo do caminho. A jornada é tortuosa e o sofrimento dos Joads não acaba quando adentram a terra prometida. Os fazendeiros locais se aproveitam do grande influ xo de imigrantes e baixam drasticamente o valor dos pagamentos oferecidos a quem se dispuser trabalhar em suas plantações, em condições precárias de moradia, higiene e alimentação. Além disso, os Joads logo percebem hostilidade nos populosos acampamentos de imigrantes cheios de pessoas famintas e entre os moradores locais, receosos e descontentes com o grande fluxo de Okies . (Steinbeck, 1963).

${ }^{5}$ Okies: nativos do estado de Oklahoma (EUA). Aqui, o termo é usado para designar grupos migrantes do meio-oeste norte-americano após a crise de 1929 e durante as tempestades de areia que assolaram aquela parte do país. (Gilman, 1989).

${ }^{6}$ Texto-fonte, em Inglês: sociolinguistic stereotypes organize the raw data of actual linguistic variation into ready made and applicable categories correlating forms, communicative meaning and socio-semiotic value.

${ }^{7}$ Texto-fonte, em Inglês: "[...] such a selective and filtered recreation is never free from constraints such as the need for readability, the degree of consciousness of linguistic variation in a given linguistic commun ity, the medium, the complexity of plot, among others. Such filters and their validity are, as such, contextually motivated and, as a consequence, intricately as sociated with a given space and time".

${ }^{8}$ Do texto-fonte, em Inglês: "Formal linguistic markers used to recreate less prestigious and substandard discourse".

${ }^{9}$ Do texto-fonte em Inglês: "The majority of shifts, then, are not determined by systemic, formal differences. The majority of shifts are non-obligatory, norm-governed, contextually motivated by cultural, ideological and political reasons.

RECEBIDO EM: 21 de janeiro de 2015

ACEITO EM: 22 de fevereiro de 2015

FAGUNDES. Uma nova perspectiva na tradução de variedades linguísticas no Brasil: um estudo preliminar Belas Infiéis, v. 4, n. 1, p. 21-38, 2015. 